This is a paper published in ECOLOGICAL APPLICATIONS. This paper has been peer-reviewed and includes the final publisher proofcorrections and journal pagination.

Citation for the published paper:

Colding, J., Lundberg, J., Lundberg, S. and Andersson, E. (2009) Golf courses and wetland fauna. Ecological applications. Volume: 19

Number: 6, pp 1481-1491.

http://www.esajournals.org/doi/abs/10.1890/07-2092.1

Access to the published version may require journal subscription. Published with permission from: Ecological Society of America.

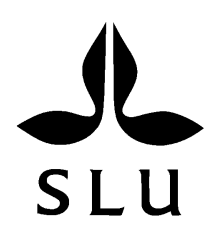

Epsilon Open Archive http://epsilon.slu.se 


\title{
Golf courses and wetland fauna
}

\author{
Johan Colding, ${ }^{1,2,5}$ Jakob Lundberg, $^{2}$ Stefan Lundberg, ${ }^{3}$ and Erik Andersson ${ }^{4}$ \\ ${ }^{1}$ The Beijer Institute of Ecological Economics, Royal Swedish Academy of Sciences, Box 50005, 10405 Stockholm, Sweden \\ ${ }^{2}$ The Stockholm Resilience Centre, Stockholm University, 10691 Stockholm, Sweden \\ ${ }^{3}$ The Swedish Museum of Natural History, Box 50007, 10405 Stockholm, Sweden \\ ${ }^{4}$ Southern Swedish Forest Research Centre, Swedish University of Agricultural Sciences, Box 49, SE-23053, Alnarp, Sweden
}

\begin{abstract}
Golf courses are often considered to be chemical-intensive ecosystems with negative impacts on fauna. Here we provide evidence that golf courses can contribute to the support and conservation of wetland fauna, i.e., amphibians and macroinvertebrates. Comparisons of amphibian occurrence, diversity of macroinvetebrates, and occurrence of species of conservation concern were made between permanent freshwater ponds surveyed on golf courses around Sweden's capital city, Stockholm, and off-course ponds in natureprotected areas and residential parklands. A total of 71 macroinvertebrate species were recorded in the field study, with no significant difference between golf course ponds and offcourse ponds at the species, genus, or family levels. A within-group similarities test showed that golf course ponds have a more homogenous species composition than ponds in natureprotected areas and ponds in residential parkland. Within the macroinvertebrate group, a total of 11 species of odonates were identified, with no difference detected between the categories of ponds, nor any spatial autocorrelation. Significant differences were found between pond categories in the occurrence of five species of amphibians, although anuran occurrence did not differ between ponds. The great crested newt (Triturus cristatus) was significantly associated with golf course ponds, but the smooth newt (Triturus vulgaris) was not. We found no evidence of any correlation between pond size and occurrence of amphibians. Among the taxa of conservation concern included in the sample, all amphibians are nationally protected in Sweden, with the internationally threatened $T$. cristatus more frequently found in golf course ponds. Among macroinveterbrates of conservation status, the large white-faced darter dragonfly (Leucorrhinia pectoralis) was only detected in golf course ponds, and Tricholeiochiton fagesi (Trichoptera) was only found in one off-course pond. GIS results revealed that golf courses provide over a quarter of all available permanent, freshwater ponds in central greater Stockholm. We assert that golf courses have the potential to contribute to wetland fauna support, particularly in urban settings where they may significantly contribute to wetland creation. We propose a greater involvement of ecologists in the design of golf courses to further bolster this potential.
\end{abstract}

Key words: amphibians; biodiversity; conservation; ecosystem management; golf courses; land use; macroinvertebrates; odonates; ponds; wetlands.

\section{INTRODUCTION}

Considering that the great majority of threatened and endangered species occur on private lands, e.g., $>90 \%$ in the United States (Scott et al. 2001), it is often suggested that such lands should be more closely integrated in biodiversity management schemes (Oldfield et al. 2003, Kiesecker et al. 2007). The Millennium Ecosystem Assessment (MA) and the Ecological Society of America (ESA) have also called for more initiatives to improve cooperation and forge partnerships among people and different sectors in society to bolster ecosystem management (MA 2005, Palmer et al. 2005). In this paper we examine the potential of the recreational land use of golf

Manuscript received 22 December 2007; revised 17 September 2008; accepted 12 November 2008. Corresponding Editor: W. V. Reid.

${ }^{5}$ E-mail: Johanc@beijer.kva.se in nature conservation and management with a focus on wetland fauna.

Currently, there exist over 31500 golf courses worldwide (Tanner and Gange 2005), with some geographical parts, e.g., Europe and the United States, having experienced rapid golf course development in recent decades. Europe holds $\sim 5800$ golf courses. Their establishment increased by an average of $5 \%$ per year between 1990 and 2000 (EIGCA 2007). The 17000 or so golf courses in the United States cover $>600000$ ha of land (Birchfield and Deters 2005), a land area larger than the state of Delaware and nearly half of Connecticut. The number of new courses constructed in the United States in the 1970s through the 1990s averaged $>300$ courses per year, i.e., nearly one new golf course per day was constructed during this 30-year period (Nicholls and Crompton 2007). Golf course development has also been burgeoning in parts of Australia (Hodgkison et al. 2007), Japan (Yasuda and Koike 
2006), and Southeast Asia, and is booming in China, where local governments believe golf courses attract investors.

Despite the large number of golf courses and the vast land area they occupy, few ecological studies on them exist in the scientific literature. High avifauna species richness, diversity, and abundance have been found on golf courses, including threatened and regionally declining bird populations (e.g., Cristol and Rodewald 2005, Merola-Zwartjes and DeLong 2005, Rodewald et al. 2005), and other species of conservation concern (Hodgkison et al. 2007), as well as essential pollinators, and predators of noxious insects (e.g., Blair and Launer 1997, Gange and Lindsay 2002). Golf courses also preserve endangered habitat types, such as dune grassland and inland heathland in Europe (Gange et al. 2003) and riparian vegetative communities and the eastern longleaf pine (Pinus palustris) ecosystems in the United States (Heuberger and Putz 2003, MerolaZwartjes and DeLong 2005).

Considerably less attention has been given to the value of golf courses for aquatic-dependent biota, despite the fact that water bodies normally are incorporated on golf courses to provide hazard features. It has been estimated that a typical English golf course contains some $2 \%$ (or roughly $1.1 \mathrm{ha}$ ) of wetland cover (Dair and Schofield 1990). These wetlands consist of permanent lakes and ponds, streams, creeks, and estuaries, as well as seasonal wetlands (Scott et al. 2002). While a number of studies have evaluated the movement of fertilizers and pesticides from golf courses to groundwater and surface water (see, e.g., Ryals et al. 1998, Lewis et al. 2001), with a major review by Cohen et al. (1999), which concludes that there are generally no significant human toxicological impacts, little is known about golf courses' chemical impacts on wetland fauna (Winter et al. 2002). To our knowledge, this paper represents the first peer-reviewed, European assessment of amphibians and macroinvertebrates in golf course water bodies, with a focus on central greater Stockholm, the capital province of Sweden. In this region, chemical inorganic applications, i.e., fertilizers (primary macronutrients) and pesticides, are regularly used on arable land and pastures, but also intensively used for turf management on golf courses. In Swedish agricultural regions both private and public water sources may be contaminated from leakage of nitrogen (Jansson and Colding 2007), with censuses showing the presence of pesticides in wells from contamination of groundwater (SNV 1999a). It has been estimated that between 0.1\% and $0.3 \%$ of pesticides associated with agriculture ultimately reach lakes and other bodies of water (SNV 1999b), with potentially harmful impacts on aquatic biota (Karlström 1995).

Inorganic chemicals are, however, considerably less used in Sweden on publicly managed parklands, and completely avoided in nature-protected areas. In Stockholm, for example, it is prohibited to use pesticides in the management of parklands for public access, with the exception of treatment of the invasive giant hogweed (Heracleum mantegazzianum) (MariaGamla stans stadsdelsförvaltning 2005). Moreover, fertilizers are sparsely used in park management.

This discrepancy in land management regimes allowed us to test whether permanent freshwater ponds on golf courses differ from those in off-course ponds, located in nature-protected areas and residential parklands, regarding amphibian occurrence and diversity of macroinvertebrates, including species of conservation concern (i.e., internationally red-listed and nationally protected species). We hypothesized that golf courses represent chemically stressed environments for pond-dependent fauna, and reasoned that a difference in fauna would be expressed between golf course ponds and off-course ponds due to difference in land management. In addition to the fauna inventory, we generate data on pond distribution in central greater Stockholm by way of a geographic information system (GIS).

\section{Focal organism groups}

Amphibians, and several macroinvertebrates, e.g., odonates (Anisoptera) and damselflies (Zygoptera), are in decline in many parts of the world (Houlahan et al. 2000, Carchini et al. 2005). Amphibians are generally more sensitive to environmental toxins and trophic disturbance than other vertebrate groups, due to their exposure to both terrestrial and aquatic habitats during their life cycles, as well as because they are relatively long lived, and highly philopatric (Welsh and Ollivier 1998, Alford and Richards 1999). Because amphibians have highly permeable skin, they may be particularly susceptible to both soil and water contaminants (Howard et al. 2002). There are many studies demonstrating harmful effects on amphibians from waters contaminated by pesticides and fertilizers (e.g., Watt and Oldham 1995, Raloff 1998). In addition to environmental acidity and toxicants, amphibian declines and losses have complex causes, e.g., ultraviolet radiation, predation, habitat modification, stochastic extinctions, alteration in climate and weather patterns, and interactions among these factors (Alford and Richards 1999, Marsh and Trenham 2001). In Europe, amphibian declines are primarily associated with habitat modification, including draining of wetlands, which increases the probability of regional extinctions (Alford and Richards 1999). Urbanization is also recognized as a key factor in the loss of bodies of water and the elimination of many amphibian populations (Rubbo and Kiesecker 2005), where the spread of highly developed land acts as barriers to dispersal between amphibian breeding habitats (Fahrig et al. 1995, Marsh and Trenham 2001). Semiaquatic species like amphibians breed and lay eggs in wetlands during short breeding seasons of a few days or weeks, and during the rest of the year migrate to terrestrial habitats to forage and overwinter (Semlitsch and Bodie 2003). 
Sweden holds 13 recorded amphibian species, with five inhabiting the Stockholm region, including the common toad (Bufo bufo), the moor frog (Rana arvalis), the common frog ( $R$. temporaria), the smooth newt (Triturus vulgaris), and the great crested newt ( $T$. cristatus). Declines of these amphibians have been documented in Stockholm from time-series censuses. From 1992 to 1996, a significant decline was recorded for the common frog ( $R$. temporaria), while the other species increased in the number of breeding sites examined (i.e., small lakes, seasonal wetlands, and permanent ponds). However, the total number of water bodies occupied by any amphibian species has decreased, with an associated increase of species cooccurrence in localities (Löfvenhaft et al. 2002).

Macroinvertebrates are regularly used for monitoring change and conditions in freshwaters in Sweden (e.g., Wiederholm and Johansson 1999) and elsewhere (e.g., Winter et al. 2002). Odonates (i.e., dragonflies) have been used more widely as bioindicators, especially larvae that often live several years at a site, and thus provide a means of ensuring continuity in sampling of water conditions for both running and still waters (Stewart and Samways 1998, Carchini et al. 2005, Foote and Rice Hornung 2005). For example, odonates have been used as indicator species for evaluating the habitat value of ponds (Carchini et al. 2005), and as a criterion for the selection of Sites of Special Scientific Interest (SSSIs) in the United Kingdom (Briers and Biggs 2003). Because odonates inhabit both aquatic and terrestrial habitats during their life cycle, they may better reflect disturbance to the transitional riparian buffer, as compared with strict wetland obligates (Foote and Rice Hornung 2005).

With a distribution continuum from temporary to permanent waters, Europe holds 164 species of odonates, out of which $37 \%$ are considered to be threatened, and with populations as a whole presently declining (McLean et al. 1999, Carchini et al. 2005). Habitat fragmentation is a primary cause of this decline, resulting in nonrandom population extinctions (Purse et al. 2003). Sweden holds a total of 61 species of odonates, with five nationally red-listed and six internationally protected, according to the European Habitat Directive, Annex II and IV (Dannelid et al. 2008). In the most recent survey of greater Stockholm, a total of 38 species of odonates were recorded (Ekestubbe et al. 2003).

\section{Methods}

\section{Study area characteristics}

Of Europe's $>6000$ golf courses, Sweden holds 499 courses, covering 25500 ha of land (SCB 2006, SGF 2007). Sweden is the fifth most golf-course-rich country in Europe. The great majority of these courses are confined to urban areas, representing privately managed lands that sometimes are owned by local clubs. Greater Stockholm constitutes some 101100 ha of land, and has
24 golf courses, making up $1.6 \%$ of the land area. These courses are scattered within a mosaic composed of urban built-up land, publicly managed parklands, forested land, and a tiny portion of arable land (Colding et al. 2006). A median-sized golf course in this area covers 57 ha, with $70 \%$ representing nonplayable areas that comprise smaller hillside patches, wetlands, stream banks, grasslands, groves, and woodlands (Colding et al. 2006). Hence, some 40 ha of a typical golf course consist of natural habitats. Considering that a Swedish mediansized nature reserve makes up some 20 ha of land (Nilsson and Götmark 1992), golf courses represent quite large, seminatural ecosystems. These golf courses also contain a considerable amount of water bodies (e.g., ditches, creeks, and ponds), with some courses holding between 10 and 20 ponds (Colding et al. 2006). Fauna surveillance of this study was restricted to a 50 700-ha study area, referred to here as central greater Stockholm (Fig. 1).

\section{Study design and criteria for analyses}

Ponds of interest in this study were those that can be defined as permanent, lentic water bodies (both manmade and natural), between $25 \mathrm{~m}^{2}$ and 2 ha in area, following the definition used by Collinson et al (1995). A total of 24 ponds were selected for analysis of fauna: 12 golf course ponds (GPs) and 12 off-course ponds (OPs). For a map of pond distribution, see Fig. 1. A random sample (without replacement) of ponds was surveyed at the six most centrally located 18-hole golf courses around Stockholm city; hence, these courses could be characterized as highly urban impacted. They were all constructed in the years 1926 to 1987 , with four created before 1933. One of these courses held only one pond that was searchable (the other was under reconstruction during our sampling period), with remaining courses having two or more ponds (range $=2-13$ ponds), where two ponds per course were surveyed. To obtain our preset sample size of 12 golf course ponds, three ponds were therefore surveyed at the course having the greatest number of ponds.

For selection of off-course ponds we used a highresolution digital map (1:10.000) of real estates, available from the National Land Survey of Sweden (Lantmäteriverket 2005). The 12 off-course ponds (OPs) were deliberately selected for surveillance of fauna. To limit the influence of geographic differences, each off-course pond was selected based on the closest distance from a given, surveyed golf course, and its location in publicly managed parkland or natureprotected area. Based on these criteria, seven off-course ponds were chosen for fauna surveillance in parklands, and five in nature-protected areas.

A GIS assessment was also carried out in the 50700 ha study area, to determine the number, area, and proportion of permanent, lentic freshwater ponds, using ArcView v.3.2 GIS software (ESRI, Redlands, California, USA). For construction of the pond GIS layer, the 


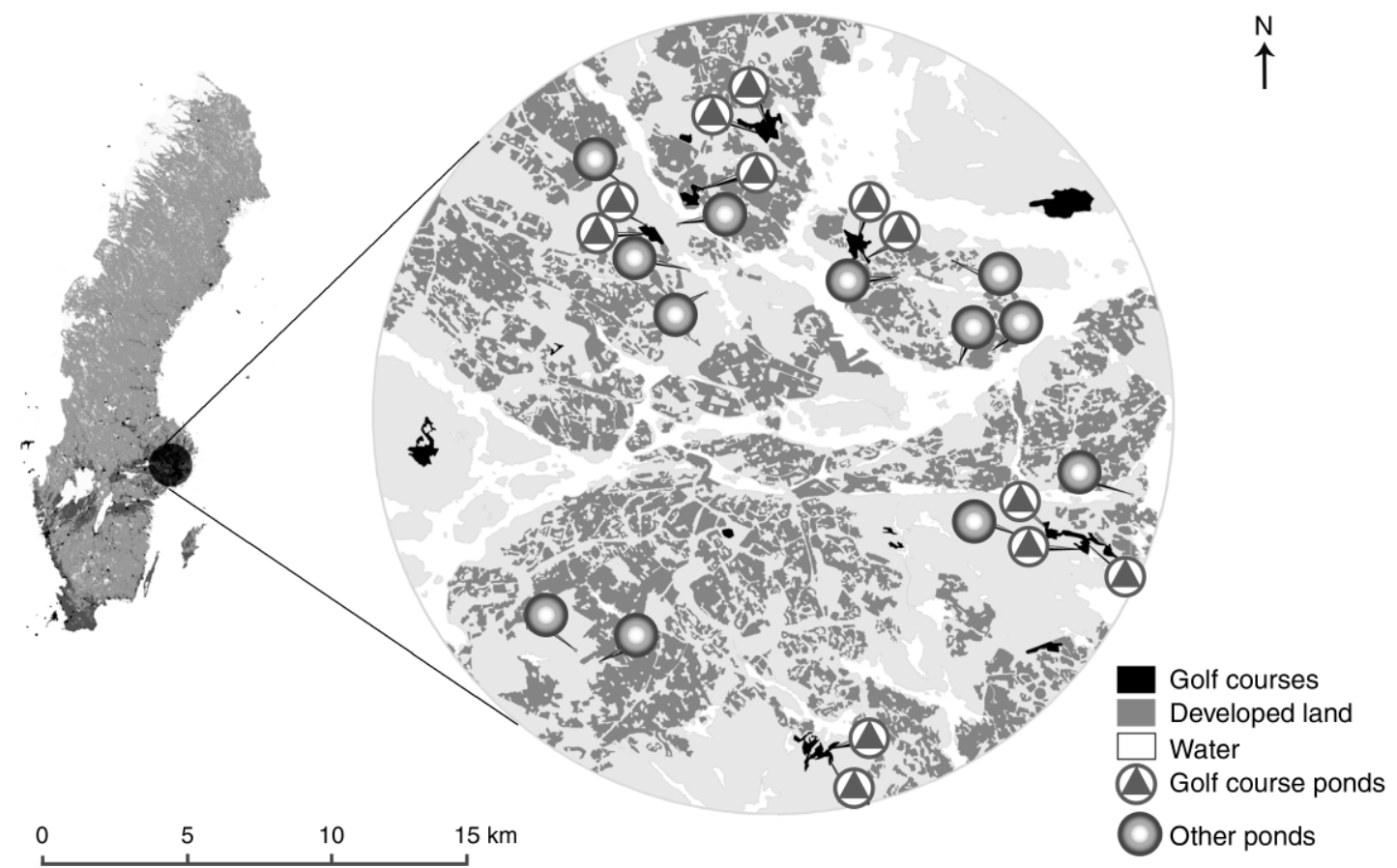

FIG. 1. Study area and distribution of 24 surveyed ponds in central greater Stockholm, Sweden.

following sources were used: a high-resolution digital map (1:10.000) available from the National Land Survey of Sweden (Lantmäteriverket 2005); the 1998 Stockholm biotope database; local orienteering maps of forest areas where ponds were harder to identify, due to tree shadowing; course maps of local golf courses; and, black-and-white digital aerial photos from a database provided by the National Land Survey (available online). ${ }^{6}$

\section{Fauna survey}

Fauna was sampled during spring and early summer of 2005 (4 May to 7 June) with sites positioned by GPS for GIS compatibility. At each site we determined pond size and the closest distance between a pond and any forest and/or shrub patch to determine potential terrestrial habitats of recorded amphibians. Terrestrial patches ranged from smaller shrub and tree patches to rather large forested areas with a mixture of native deciduous and coniferous trees.

Macroinvertebrates were sampled using a standard water net (mesh size $0.5 \times 0.5 \mathrm{~mm}$ ) in a $50 \mathrm{~cm}$ wide section outwards from the shoreline among the aquatic vegetation. An area of 9-25 $\mathrm{m}^{2}$ was sampled with kicksampling technique at each pond, depending on the size and structure of the ponds, assumed to represent the overall macroinvertebrate fauna associated with the different pond substrates (Sahlén and Ekestubbe 2001). The daytime sampling was carried out by the same

${ }^{6}\langle$ https://geoimager.lantmateriet.se/digibib/〉 person with an effort to achieve random sampling. Each pond was visited once with collected fauna assemblages preserved in $80 \%$ alcohol in the field, and identified at the laboratory to the level of individual taxa, i.e., species, genera, or families.

Amphibians were detected between dusk and midnight using visual encounter surveys (VES) by way of torchlight [using flashlights] (Campbell and Christman 1982). We counted the number of different adult amphibian species by walking around the pond, scanning every meter or so as gaps in pond bank vegetation allowed. Smaller ponds $\left(<200 \mathrm{~m}^{2}\right)$ allowed for the whole water column to be surveyed by torching [shining flashlights]. At larger ponds, circumscribed banks (approximately $\leq 1 \mathrm{~m}$ water depth) were surveyed where vegetation gaps occurred. An effort was also made to encounter adult amphibians present in the vicinity of the ponds (approximately $\leq 50 \mathrm{~m}$ ). To reduce possible influence from weather, we strived to sample amphibians in golf course ponds and off-course ponds that were located within the same geographic cluster during a given sampling day. Because amphibian behavior and site attributes vary seasonally and temporally with weather and internal rhythms of the animals (Alford and Richards 1999), sites with no observations of amphibians were revisited once to assure that they did not contain amphibians.

\section{Statistical analyses}

Differences in species composition of macroinvertebrates and amphibians were tested statistically using one-way analysis of similarities (ANOSIM) randomiza- 
tion test (Clark 1988), a nonparametric analogue to the standard univariate one- and two-way ANOVA tests. Analyses were done with the PRIMER v.6 software (Clarke and Gorley 2006).

To exclude potential deviations caused by the high number of individual taxa in some ponds, two separate runs were performed: one untransformed test (giving more weight to dominant species), and one on presence/absence. Due to difficulties with the identification of some organisms, tests for macroinvertebrates were run three times on different taxonomic levels: species, genera, and family. Since we had two types of off-course ponds, we also ran a set of analyses where ponds were classified in three categories of land use: golf courses, nature-protected areas, and residential parklands. Within-group similarities were checked for the three different pond categories. We also ran a more specific test on the species within the order Odonata. Within the amphibian group, separate tests were run for great crested and smooth newts (Mann-Whitney $U$ test), respectively, and one for anurans (ANOSIM). A version of Mantel's test designed to test matched similarity matrices (called RELATE in PRIMER) was used to check for potential spatial autocorrelations. We also controlled for the different pond sizes by running a correlation analysis between pond size and the occurrence of the different amphibians.

\section{RESULTS}

A total of 71 macroinvertebrate species were recorded in the field study. For macroinvertebrates there was no significant difference between golf course ponds and off-course ponds at any taxonomic level (species, genera, family), represented here by the species level, since it contains most data (untransformed, $R=0.04, P$ $=0.167$; presence/absence, $R=0.016, P=0.352$ ). No statistically significant evidence of spatial autocorrelation was found (Rho $=0.064, P=0.243$ ). We found some weaker support for differences between ponds when we divided them into three categories (Untransformed, $R=0.16, P=0.051$; Presence/Absence, $R=$ $0.135, P=0.056)$, where the only significant pairwise difference was for presence/absence transformed data from golf course and residential parklands (Presence/Absence, $R=0.234, P=0.018$ ). Within-group similarities test showed that golf course ponds have a more homogenous species composition (average similarity: 32.27), compared with ponds in nature-protected areas (average similarity: 18.27) and ponds in residential parkland (average similarity: 14.89).

Within the macroinvertebrate group a total of 11 species of odonates were identified (Fig. 2), with 6 recorded in golf course ponds and 8 recorded in offcourse ponds. However, no difference could be detected between the pond categories (Untransformed, $R=0.001$, $P=0.408$; Presence/Absence, $R=-0.001 ; P=0.44)$, nor any spatial autocorrelation $(\mathrm{Rho}=0.065, P=0.206)$.
In total we recorded five species of amphibians (Fig. 3). We obtained a significant difference for amphibians between golf course ponds and off-course ponds (Untransformed, $R=0.129, P=0.012$; Presence/Absence, $R=0.137, P=0.009$ ) with no statistical indication of spatial autocorrelation $(\mathrm{Rho}=0.083, P=$ 0.188 ). Anurans did not differ between ponds (Untransformed, $R=0.019, P=0.186$; Presence/Absence, $R=$ $0.025, P=0.199)$. Nonparametric independent samples comparison by Mann-Whitney $U$ test revealed that the great crested newt was significantly associated with golf course ponds $(Z=2.05, P=0.04)$ while the smooth newt was not $(Z=1.41, P=0.157)$. We found no evidence of any correlation between pond size and occurrence of amphibians.

Among taxa of conservation concern, two represent internationally red-listed species, i.e., the great crested newt and the large white-faced darter dragonfly (Leucorrhinia pectoralis), registered as "near threatened" in Appendix II of the Bern Convention, with the latter species only detected in golf course ponds. Moreover, Tricholeiochiton fagesi (Trichoptera), found in one offcourse pond, is nationally red-listed (Gärdenfors 2005). In addition, all amphibians encountered in this study are nationally protected.

GIS results revealed that 167 freshwater ponds were confined to the study area, of which 44 (i.e., 26.3\%) represent golf course ponds. This corresponds to well over twice the number of ponds found in protected areas, with golf course ponds making up a greater total pond area than ponds confined to nature-protected areas (Table 1). Ponds used in surveillance of fauna ranged in size from $50 \mathrm{~m}^{2}$ to $10.350 \mathrm{~m}^{2}$ (Table 2), with a mean size of $769 \mathrm{~m}^{2}$ and $3104 \mathrm{~m}^{2}$ for golf course ponds and off-course ponds, respectively. The measured distance between any pond and its nearest forest patch is given in Table 2.

\section{Discussion}

\section{Golf course ponds as habitats for macroinvertebrates and amphibians}

Our hypothesis that golf course ponds in central greater Stockholm represent chemically stressed habitats of little value for wetland fauna is not supported by the field data. We found no evidence that golf course ponds differ in providing habitats for macroinvertebrates (at any taxonomic level) relative to other types of ponds examined in this study. This relationship was true regardless of where golf courses were located in the study area. Interestingly, we found no significant difference in species composition between golf course ponds and ponds located in nature-protected areas. The only significant difference found was between golf course ponds and ponds located in residential parklands.

Two odonate species were only recorded in golf course ponds, including the large white-faced darter dragonfly (Leucorrhinia pectoralis) and the common blue damselfly (Enallagma cyathigerum), with the former 


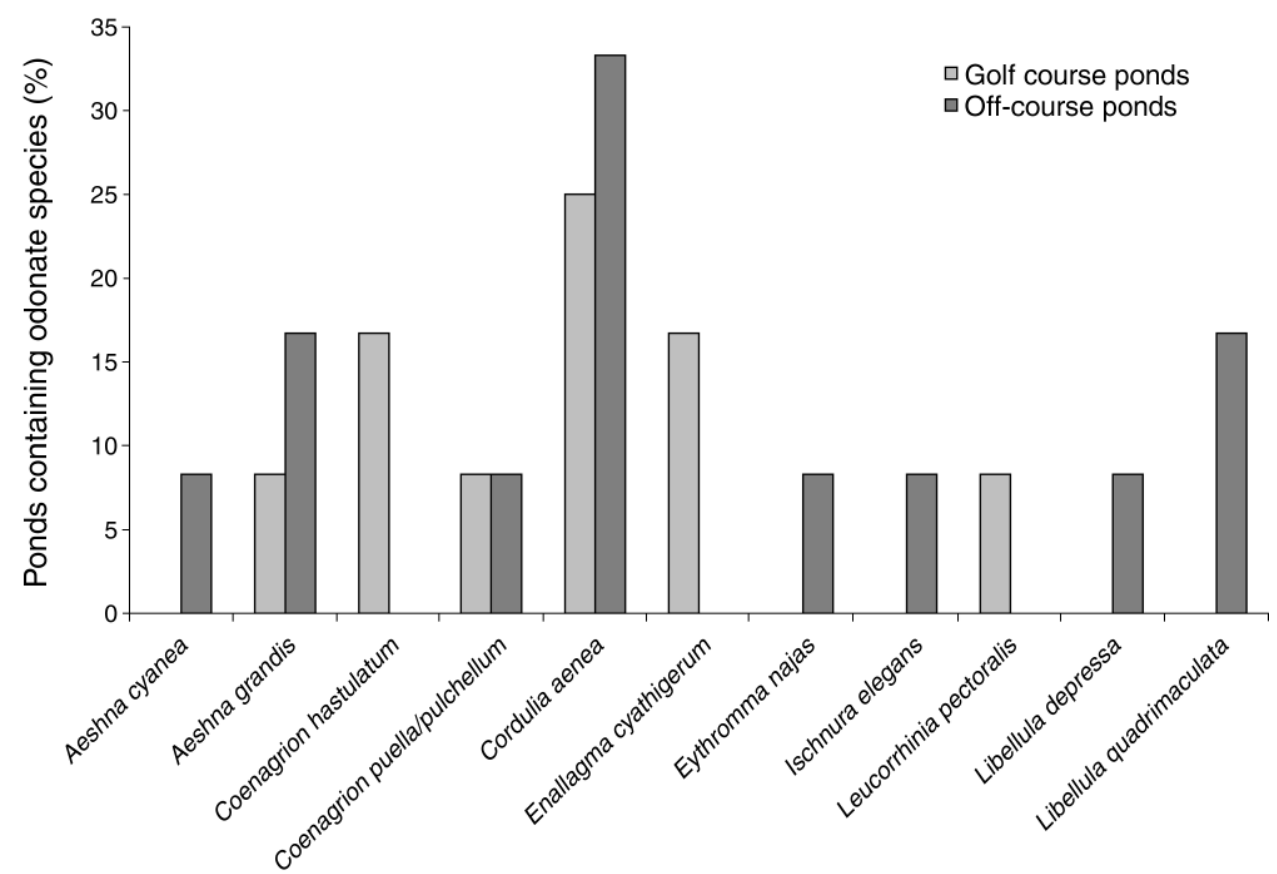

FIG. 2. Species of Odonata recorded in the case study, by pond location on or off golf courses.

being internationally red-listed. The presence of these species correlates with aquatic plant richness in Sweden (Sahlén and Ekestubbe 2001).

A significant difference for amphibians between pond categories was obtained. Anurans did not differ; however, the study reveals that golf course ponds are suitable habitats for newts. Both of the newt species in Sweden occurred in golf course ponds, with the great crested newt significantly associated with these ponds.
This species strongly depends on water bodies with low levels of pollutants and acidification (Karlström 1995, Marsh and Trenham 2001, Andrén 2004). Moreover, the great crested newt is vulnerable to the presence of fish (Beebee 1985, Karlström 1995, Joly et al. 2001), and depends on fine-leaved water vegetation for egg laying (Miaud 1995), suggesting that ponds containing this species in general are fish free and provide suitable plant substrates necessary for its reproduction.

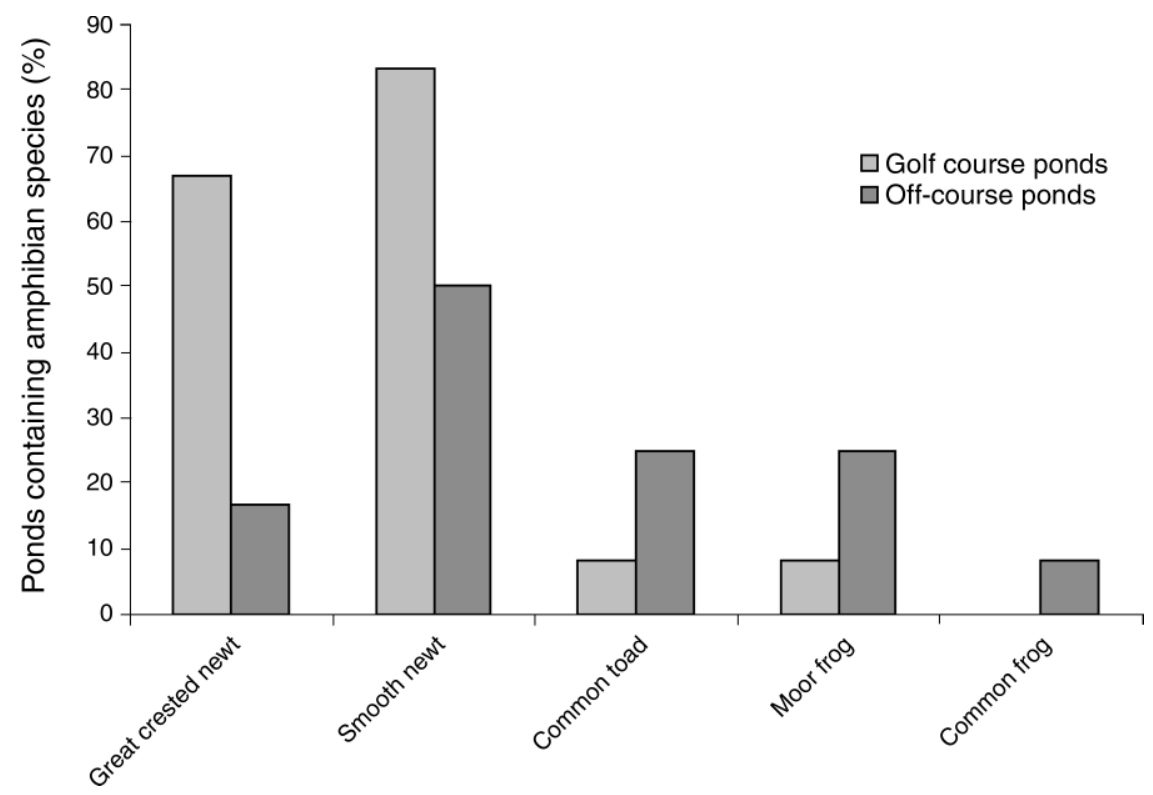

FIG. 3. Amphibians recorded in the case study, by pond location on or off golf courses. 
TABLE 1. GIS data for pond distribution in central greater Stockholm.

\begin{tabular}{|c|c|c|c|c|c|}
\hline \multirow[b]{2}{*}{ Location } & \multirow[b]{2}{*}{ Land area (ha) } & \multicolumn{2}{|c|}{ Number of ponds } & \multicolumn{2}{|c|}{ Aggregated pond area (ha) } \\
\hline & & Total & In this study & Total & In this study \\
\hline $\begin{array}{l}\text { Golf clubs, } n=13 \\
\text { Nature-protected, } n=16 \\
\text { Miscellaneous, including residential land }\end{array}$ & $\begin{array}{r}571.7 \\
4766.2 \\
45370.7\end{array}$ & $\begin{array}{r}44 \\
21 \\
102\end{array}$ & $\begin{array}{r}12 \\
5 \\
7\end{array}$ & $\begin{array}{r}4.4 \\
3.6 \\
31.0\end{array}$ & $\begin{array}{l}0.92 \\
1.60 \\
2.13\end{array}$ \\
\hline Total & 50708.6 & 167 & 24 & 39.0 & 4.65 \\
\hline
\end{tabular}

While golf course ponds appear to be highly suitable habitats for newts, adult anurans could only be detected in one of the golf course ponds of the survey, containing the common toad and the moor frog. This pond lacked the great crested newt. More generally, no anurans were found in ponds in which the great crested newt occurred. This may be due to the fact that the great crested newt is a known predator of anuran tadpoles, among others, which means that frog survival can be lower in cases of coexistence between anurans and newts (Karlström 1995). This effect has also been described for other species of newts (e.g., Wilbur et al. 1983). In addition to the threatened great crested newt, which thrived in golf course ponds, the large white-faced darter dragonfly also represents an internationally red-listed species that has declined greatly in many parts of Europe and has high conservation priority in the EU Habitats Directive (the Council Directive 92/43/EEC). This species could only be found in three geographically separated golf course ponds. Based on overall results of this study, we provide four major assertions regarding golf courses and wetland fauna.

\section{Chemicals on golf courses}

The use of chemical applicants on golf courses in central greater Stockholm does not seem to have a negative effect on the organism groups examined. This finding is quite unexpected, considering that Swedish golf courses are intensively managed with chemical applicants. For example, recommended nitrogen treatment of putting greens is in the range of $150-300 \mathrm{~kg} \cdot \mathrm{ha}^{-1} \cdot \mathrm{yr}^{-1}$, usually distributed 8-15 times, and in the range of 0 $150 \mathrm{~kg} \cdot \mathrm{ha}^{-1} \cdot \mathrm{yr}^{-1}$ for fairways (Golfsportens miljöpåverkan 2000). Phosphorus is usually only applied on Swedish golf courses during construction, while potassium is applied regularly and in as large a quantity as nitrogen (Golfsportens miljöpåverkan 2000). Regarding pesticides, fungicides are almost exclusively used on putting greens to treat fungi, predominantly Monographella nivalis. Herbicides are used to treat weeds on fairways, mainly white clover (Trifolium repens). In comparison, recommended use of nitrogen on intensively managed farmland is $175-225 \mathrm{~kg} \cdot \mathrm{ha}^{-1} \cdot \mathrm{yr}^{-1}$ (Jordbruksverket 1997). These levels have been shown to negatively influence amphibian occurrence in greater Stockholm (Karlström 1995).

TABLE 2. Pond parameters and biodiversity indices for assessed macroinvertebrates (identified to species level).

\begin{tabular}{|c|c|c|c|c|c|c|}
\hline Ponds & Area $\left(\mathrm{m}^{2}\right)$ & $\begin{array}{l}\text { Distance to nearest } \\
\text { forest patch }(\mathrm{m})\end{array}$ & $\begin{array}{l}\text { Number of } \\
\text { species, } S\end{array}$ & $\begin{array}{c}\text { Total } \\
\text { individuals }(n)\end{array}$ & $\begin{array}{c}H^{\prime} \\
(\log 10) / \log (S)\end{array}$ & $\begin{array}{c}\text { Shannon index } H^{\prime} \\
(\log 10)\end{array}$ \\
\hline G1 & 500 & 38 & 7 & 231 & 0.32 & 0.62 \\
\hline G2 & 70 & 17 & 6 & 369 & 0.49 & 0.89 \\
\hline G3 & 580 & 29 & 10 & 1191 & 0.24 & 0.56 \\
\hline G4 & 1440 & 75 & 14 & 994 & 0.50 & 1.32 \\
\hline G5 & 2000 & 72 & 12 & 311 & 0.52 & 1.28 \\
\hline G6 & 1060 & 55 & 16 & 4301 & 0.16 & 0.44 \\
\hline G7 & 1330 & 50 & 13 & 453 & 0.68 & 1.75 \\
\hline G8 & 90 & 10 & 16 & 546 & 0.62 & 1.72 \\
\hline G9 & 140 & 12 & 15 & 1457 & 0.44 & 1.20 \\
\hline G10 & 1130 & 1 & 10 & 494 & 0.63 & 1.44 \\
\hline G11 & 800 & 15 & 17 & 1060 & 0.75 & 2.13 \\
\hline $\mathrm{G} 12$ & 90 & 10 & 8 & 279 & 0.73 & 1.51 \\
\hline OP13 & 5930 & 1 & 15 & 162 & 0.74 & 2.00 \\
\hline OP14 & 3220 & 7 & 16 & 586 & 0.62 & 1.71 \\
\hline OP15 & 2840 & 1 & 10 & 841 & 0.36 & 0.82 \\
\hline OP16 & 50 & 30 & 10 & 378 & 0.54 & 1.24 \\
\hline OP17 & 550 & 49 & 6 & 119 & 0.62 & 1.11 \\
\hline OP18 & 6240 & 1 & 17 & 519 & 0.64 & 1.83 \\
\hline OP19 & 3910 & 25 & 7 & 633 & 0.59 & 1.15 \\
\hline OP20 & 1750 & 1 & 25 & 586 & 0.66 & 2.14 \\
\hline OP21 & 1210 & 1 & 3 & 11 & 0.91 & 0.99 \\
\hline OP22 & 110 & 1 & 3 & 11 & 0.55 & 0.60 \\
\hline OP23 & 10350 & 90 & 18 & 972 & 0.37 & 1.07 \\
\hline OP24 & 1090 & 7 & 15 & 437 & 0.46 & 1.24 \\
\hline
\end{tabular}

Note: A total of 24 ponds were selected for analysis of fauna: 12 golf course ponds (G) and 12 off-course ponds (OP). 
There might be several reasons why fertilizers applied on the golf courses studied do not impact wetland fauna negatively. One reason is that golf course ponds examined were randomly selected in this study, which means that we did not differentiate among golf course ponds adjacent to putting greens (which are more intensively treated with chemicals) and ponds positioned on fairways or out-of-play areas on the golf course. This means that we might have missed golf course ponds that potentially were more contaminated than others. On the other hand, excessive chemicals may eventually reach ponds on a golf course over time through drift outside of the intended areas where they are applied, or they may percolate, or leach, through the soil, as well as be carried to ponds as runoff (States of Jersey 2007).

Another reason is that Swedish golf courses represent habitats with a considerably longer yearly period of plant cover relative to intensively managed arable land (e.g., cropland), which is barren for long intervals, i.e., in the winter and fall. This means that nutrient uptake by plants is considerably greater on a golf course. Such buffering effect of vegetation cover may explain why fertilizers on the golf courses assessed do not reach harmful levels for wetland fauna. It should be recognized, however, that chemical applications on golf courses can promote amphibian tadpole survival. For example, studies from the United States show that insecticides may increase food resources for amphibians through reduced interspecific competition between amphibians and aquatic insects (Semlitsch et al. 2007). Moreover, insecticides can lead to a reduction of insect predators that consume amphibian eggs and larvae (Semlitsch et al. 2007). The use of insecticides on Swedish golf courses is, however, limited and usually only applied to treat frit flies (Chloropidae) on putting greens (Golfsportens miljöpåverkan 2000).

\section{Golf course pond management}

A second assertion we make is that golf course pond management benefits groups of wetland fauna. The natural fate of all bodies of standing freshwater is to fill with sediment and vegetation and gradually change to terrestrial habitat (Gee et al. 1997). However, due to aesthetic ideals and in order to fulfil high playing standards, golf course ponds are regularly maintained through the removal of vegetation, preventing natural succession from reaching the stage where water bodies become overgrown and ultimately drained. As confirmed in talks with greens keepers at the golf courses assessed, this practice is routinely conducted on Swedish golf courses. This practice benefits some amphibians (Marsh and Trenham 2001) and macroinvertebrates, e.g., odonates (Schindler et al. 2003). For instance, the two species of newts recorded in this study depend on open water areas for successful mating behavior (Hedlund 1990). Moreover, most Anisoptera species depend on sunny biotopes with a high percentage of exposed macrophytes (Samways and Steytler 1996). In addition to open water areas in ponds, removal of vegetation allows for continuous uptake of phosphorus and nitrogen by fast-growing plants such as cattail (Typha spp.) and the common reed (Phragmites australis), which were frequent in the ponds of this study. This practice contributes to nutrient retention because plant material is continuously harvested and removed, lowering eutrophication, which is considered to be one of the major impairments of small standing water bodies (Brönmark and Hansson 2002), with associated negative effects on amphibians (Andrén et al. 1988, Berger 1989, Oldham et al. 1997, Camargo et al. 2005). Invertebrate communities are strongly influenced by nitrate levels in ponds (Briers and Biggs 2005), with increased eutrophication leading to a reduction in the number of odonates (Lenz 1991).

While permanent water bodies may favor some groups of wetland fauna, golf courses should ideally also contain seasonal wetlands to optimize their value for fauna more generally due to the absence of predatory fish. For example, Paton and Egan (2003) and Scott et al. (2002) found that golf course ponds with a short hydroperiod tend to have unique amphibian species compared with permanent ponds. Temporary waters on golf courses may also benefit odonates. While most Anisoptera species preferentially breed in lentic, permanent waters (Brooks 1999, Hofmann and Mason 2005), many odonates avoid predators by using habitats that are too ephemeral for the predators to complete their life cycles (Wellborn et al. 1996, Johansson 2000, Johansson and Suhling 2004).

\section{Golf courses and terrestrial habitats}

A third assertion that can be made from this study is that golf courses likely also provide suitable terrestrial habitat for wetland fauna. Most pond-breeding amphibians reside in terrestrial habitat patches near breeding ponds for feeding, shelter, and hibernation (Paton and Egan 2003, Rubbo and Kiesecker 2005), and given the philopatric behavior of amphibians, we assume this relationship also holds on the golf courses surveyed. In this study, the recorded maximum distance between any golf course pond and its closest natural forest or shrub patch was between $\leq 1$ and $75 \mathrm{~m}$ (with a mean distance of $32 \mathrm{~m}$ ), a range falling well within the known movement ranges of assessed amphibians (i.e., 400-2000 $\mathrm{m}$ [Andrén 2004]). That amphibians actually use these terrestrial habitats needs, however, to be confirmed through active search surveys, although such detection is extremely difficult (Semlitsch and Bodie 2003).

Besides amphibians, the golf courses surveyed likely provide suitable terrestrial habitats for a great many of the aquatic invertebrates, e.g., odonates. It is generally known that most of the mature adult life span of odonates is spent at the breeding site (Purse et al. 2003). Zygopterans are generally weak flyers, which tend to occupy the interior of emergent vegetation stands and deposit fertilized eggs among the stalks of wetland 
vegetation (Foote and Rice Hornung 2005). In general they do not disperse far from their larval habitat, and the majority of mature adults at a pond have generally emerged from the same pond (Bennett and Mill 1995, Hardersen 2000). Adult Anisoptera, in contrast, may disperse considerably longer distances (Conrad et al. 1999).

\section{Urban golf courses and wetland fauna}

A fourth, and perhaps the most important assertion, is that golf courses located in urban areas have the potential to provide important habitats for declining groups of wetland fauna (Hodgkison et al. 2007). As revealed in this study, golf courses provide over a quarter of all permanent freshwater ponds that exist in greater Stockholm. This is a considerable resource, given that golf course ponds appear to provide habitats that are as suitable for wetland fauna as ponds in natureprotected areas. As urban wetlands in general tend to have less surrounding forest cover and a greater road density than rural wetlands (Rubbo and Kiesecker 2005), with isolation of amphibian populations (by geographic distance and/or presence of road traffic) as an important factor behind amphibian declines in greater Stockholm (Karlström 1995, Löfvenhaft et al. 2002, Löfvenhaft et al. 2004), golf course ponds are generally embedded within a coherent belt of green cover. Because the golf courses assessed represent large seminatural ecosystems, often containing a whole system of ponds, creeks, and ditches, they represent a vital refuge for local aquatic fauna populations and likely contribute to sustaining larger, regional metapopulations (Hanski 1998, Alford and Richards 1999). Furthermore, one-fifth of all golf courses in greater Stockholm are located adjacent to nature reserves (Colding et al. 2006). Given that exchange of local wetland populations occurs between these land use types, golf courses may provide important buffer habitats near reserves (Colding 2007).

\section{Conclusions}

Based on results of this study, we conclude that golf course chemicals on surveyed courses do not seem to impact aquatic fauna negatively; active golf course pond management can benefit some wetland fauna groups; the golf courses assessed likely provide terrestrial habitat for a great deal of wetland fauna; and golf courses provide a substantial amount of wetlands in urban settings. We do not suggest that golf courses in general benefit wetland fauna. However, golf courses with ample wetlands contained on them can significantly contribute to wetland fauna support, particularly in urban settings where green areas are diminishing, and loss of aquatic habitat occurs (Rubbo and Kiesecker 2005). Given that ecological premises are more widely accounted for in golf course design and management, the sport of golf could increasingly become an asset in ecosystem management and biodiversity conservation. For this to be realized, it is essential that ecologists cooperate more closely with urban planners, ecosystem managers, and golf course designers.

\section{ACKNOWLEDGMENTS}

Thanks to the Swedish research council Formas, the Department of Systems Ecology (Stockholm University) for support, and also Mistra (the Foundation for Strategic Environmental Research) for support to the Stockholm Resilience Centre. The fieldwork was additionally funded through a grant from the Scandinavian Turfgrass and Environment Research Foundation. Thanks also go to Christina Ekström and Erland Dannelid for help with species identification. We also thank the anonymous reviewers of this paper for constructive comments.

\section{Literature Cited}

Alford, R. A., and S. J. Richards. 1999. Global amphibian declines: a problem in applied ecology. Annual Review of Ecology and Systematics 30:133-165.

Andrén, C. 2004. Oskarshamn site investigation. Amphibians and reptiles in SKB special area of investigation at Simpevarp. Swedish Nuclear Fuel and Waste Management Company, Stockholm, Sweden.

Andrén, C., L. Henrikson, M. Olsson, and G. Nilsson. 1988. Effects of $\mathrm{pH}$ and aluminium on embryonic early larval stages of Swedish brown frogs Rana arvalis, $R$. temporaria and R. dalmatina. Holarctic Ecology 11:127-135.

Beebee, T. J. C. 1985. Discriminant analysis of amphibian habitat determinants in southeast England. AmphibiaReptilia 6:35-43.

Bennett, S., and P. J. Mill. 1995. Pre- and post-maturation survival in adults of the damselfly Pyrrhosoma nymphula (Zygoptera: Coenagrionidae). Journal of Zoology 235:559 575.

Berger, L. 1989. Disappearance of amphibian larvae in the agricultural landscape. Ecology International Bulletin 17:6573.

Birchfield, G. L., and J. E. Deters. 2005. Movement paths of displaced northern green frogs (Rana clamitans melanota). Southeastern Naturalist 4:63-76.

Blair, R. B., and A. E. Launer. 1997. Butterfly diversity and human land use: species assemblages along an urban gradient. Biological Conservation 80:113-125.

Briers, R. A., and J. Biggs. 2003. Indicator taxa for the conservation of pond invertebrate diversity. Aquatic Conservation: Marine Freshwater Ecosystems 13:323-330.

Briers, R. A., and J. Biggs. 2005. Spatial patterns in pond invertebrate communities: separating environmental and distance effects. Aquatic Conservation: Marine Freshwater Ecosystems 15:549-557.

Brönmark, C., and L.-A. Hansson. 2002. Environmental issues in lakes and ponds: current state and perspectives. Environmental Conservation 29:290-306.

Brooks, S. 1999. Field guide to the dragonflies and damselflies of Great Britain and Ireland. British Wildlife Publishing, Rotherwick, UK.

Camargo, J. A., A. Alonso, and A. Salamanca. 2005. Nitrate toxicity to aquatic animals: a review with new data for freshwater invertebrates. Chemosphere 58:1255-1267.

Campbell, H. W., and S. P. Christman. 1982. Field techniques for herpetofaunal community analysis. Pages 193-200 in N. J. Scott, editor. Herpetological communities. United States Department of the Interior, Fish and Wildlife Service, Washington, D.C., USA.

Carchini, G., A. G. Solimini, and A. Ruggiero. 2005. Habitat characteristics and odonate diversity in mountain ponds of central Italy. Aquatic Conservation: Marine and Freshwater Ecosystems 15:573-581. 
Clark, K. R. 1988. Detecting change in benthic community structure. Proceedings, XIVth International Biometric Conference, Namur: Invited Papers. Société Adophe Quélét, Gemblous, Belgium, 1988.

Clarke, K. R., and R. N. Gorley. 2006. PRIMER v6. PRIMER-E Ltd, Plymouth, UK.

Cohen, S., A. Svrjcek, T. Durborow, and N. L. Barnes. 1999. Water quality impacts on golf courses. Journal of Environmental Quality 28:798-809.

Colding, J. 2007. 'Ecological land-use complementation' for building resilience in urban ecosystems. Landscape and Urban Planning 81:46-55.

Colding, J., J. Lundberg, and C. Folke. 2006. Incorporating green-area user groups in urban ecosystem management. Ambio 35:237-244.

Collinson, N. H., J. Biggs, A. Corfield, M. J. Hodson, D. Walker, M. Whitfield, and P. J. Williams. 1995. Temporary and permanent ponds - an assessment of the effects of drying out on the conservation value of aquatic macroinvertebrate communities. Biological Conservation 74:125-133.

Conrad, K. F., K. H. Willson, I. F. Harvey, C. J. Thomas, and T. N. Sherratt. 1999. Dispersal characteristics of seven odonate species in an agricultural landscape. Ecography 22: 524-531.

Cristol, D. A., and A. D. Rodewald. 2005. Introduction: Can golf courses play a role in bird conservation? Wildlife Society Bulletin 33:407-410.

Dair, I., and J. M. Schofield. 1990. Nature conservation and the management of golf courses in Great Britain. Pages 330-335 in A. J. Cochran, editor. Science and golf. Spon, London, UK.

Dannelid, D., G. Liljeberg, and G. Sahlén. 2008. Trollsländor i Sverige - en fälthandbok. (Swedish Odonata - A field guide). Länsstyrelsen i Södermanlands län. Edita Västra Aros AB, Västerås, Sweden. [In Swedish only.]

EIGCA (European Institute of Golf Course Architects). 2007. Golf statistics Europe 2000. 〈http://www.eigca.org/index.php〉

Ekestubbe, K., E. Dannelid, C. Rosén, and J. Wenngren. 2003. Inventering av trollsländor i Stockholms län åren 2000-2001. Södertörnsekologerna. Rapport 2003:1. ISNN1651-856X.

Fahrig, L., J. H. Pedlar, S. E. Pope, P. D. Taylor, and J. F. Wegner. 1995. Effect of road traffic on amphibian density. Biological Conservation 73:177-182.

Foote, A. L., and C. L. Rice Hornung. 2005. Odontaes as biological indicators of grazing effects on Canadian prairie wetlands. Ecological Entomology 30:273-283.

Gange, A. C., and D. E. Lindsay. 2002. Can golf courses enhance local biodiversity? Pages 721-736 in E. Thain, editor. Science and Golf IV. Routledge, London, UK.

Gange, A. C., D. E. Lindsay, and J. M. Schofield. 2003. The ecology of golf courses. Biologist 50:63-68.

Gärdenfors, U., editor. 2005. The 2005 Red List of Swedish species. The Swedish Species Information Centre, SLU (Swedish University of Agricultural Sciences), Uppsala, Sweden.

Gee, J. H. R., B. D. Smith, K. M. Lee, and S. W. Griffiths. 1997. The ecological basis of freshwater pond management for biodiversity. Aquatic Conservation: Marine and Freshwater Ecosystems 7:91-104.

Golfsportens miljöpåverkan. 2000. Faktablad om golfbanor 200002 17. Svenska Golfförbundet, Danderyd, Sweden.

Hanski, I. 1998. Metapopulation dynamics. Nature 396:41-49.

Hardersen, S. 2000. The role of behavioural ecology of damselflies in the use of fluctuating asymmetry as a bioindicator of water pollution. Ecological Entomolgy 25: 45-53.

Hedlund, L. 1990. Reproductive ecology of crested newts, Triturus cristatus (Laur.). Dissertation. University of Uppsala. Statens Lantbruksuniversitet, Uppsala, Sweden.

Heuberger, K. A., and F. E. Putz. 2003. Fire in the suburbs: ecological impacts of prescribed fire in small remnants of longleaf pine (Pinus palustris) Sandhill. Restoration Ecology 11:72-81.

Hodgkison, S. C., J.-M. Hero, and J. Warnken. 2007. The conservation value of suburban golf courses in a rapidly urbanizing region of Australia. Landscape and Urban Planning 79:323-337.

Hofmann, T. A., and C. F. Mason. 2005. Habitat characteristics and the distribution of Odonata in a lowland river catchment in eastern England. Hydrobiologia 539:137-147.

Houlahan, J. E., C. S. Findlay, B. R. Schmidt, A. H. Meyer, and S. L. Kuzmin. 2000. Quantitative evidence for global amphibian population declines. Nature 404:752-755.

Howard, J. H., S. E. Julian, and J. Ferrigan. 2002. Golf course design and maintenance: impacts on amphibians. USGA Turfgrass and Environmental Research Online 1(2):1-21.

Jansson, A., and J. Colding. 2007. Tradeoffs between environmental goals and urban development: the case of nitrogen load from the Stockholm County to the Baltic Sea. AMBIO 36:650-656.

Johansson, F. 2000. The slow-fast life style characteristics in a suite of six species of odonate larvae. Freshwater Biology 43: 149-159.

Johansson, F., and F. Suhling. 2004. Behaviour and growth of dragonfly larvae along a permanent to temporary water habitat gradient. Ecological Entomology 29:196-202.

Joly, P., C. Miaud, A. Lehmann, and O. Grolet. 2001. Habitat matrix effects on pond occupancy in newts. Conservation Biology 15:239-248.

Jordbruksverket. 1997. Riktlinjer för gödsling och kalkning 1998. Rapport 1997:22.

Karlström, A. 1995. En naturvårdsbiologisk analys av den större vattensalamanderns (Triturus cristatus) leklokaler i Södertälje kommun. Examensarbete 20p. Institutionen för Genetik, Uppsala Universitet, Miljöförvaltningen, Södertälje kommun, Sweden.

Kiesecker, J. M., T. Comendant, T. Grandmason, E. Gray, C. Hall, R. Hilsenbeck, P. Kareiva, L. Lozier, P. Naehu, and A. Rissman. 2007. Conservation easements in context: a quantitative analysis of their use by The Nature Conservancy. Frontiers in Ecology and the Environment 5:125-130.

Lantmäteriverket. 2005. GSD Fastighetskartan, 1:10 000. Lantmäteriverket, Gävle, Sweden.

Lenz, N. 1991. The importance of abiotic and biotic factors for the structure of odonate communities of ponds (Insecta, Odonata). Faun-ökologie 6:175-189.

Lewis, M. A., S. S. Foss, P. S. Harris, R. S. Stanley, and J. C. Moore. 2001. Sediment chemical contamination and toxicity associated with a coastal golf course complex. Environmental Toxicology and Chemistry 20:1390-1398.

Löfvenhaft, K., S. Runborg, and P. Sjögren-Gulve. 2004. Biotope patterns and amphibian distribution as assessment tools in urban landscape planning. Landscape and Urban Planning 68:403-427.

Löfvenhaft, K., P. Sjögren-Gulve, M. Norström, and A. Karlström. 2002. Using amphibians as reference tool for biodiversity assessments in urban areas: significance of geographic isolation and water chemistry. Paper 2 in $\mathrm{K}$. Löfvenhaft. Spatial and temporal perspectives on biodiversity for physical planning. Dissertation. Department of Physical Geography and Quaternary Geology, Stockholm University, Stockholm, Sweden.

MA (Millennium Ecosystem Assessment). 2005. Ecosystems and human well-being: synthesis. Island Press, Washington, D.C., USA.

Maria-Gamla stans stadsdelsförvaltning. 2005. 05. 22 Arbetsbeskrivningar. Parkdrift. Renhållning, vinterväghållning och parkskötsel/-underhåll. Handling 05. 22. 2005-02-01. MariaGamla stans stadsdelsförvaltning, Stockholm, Sweden.

Marsh, D. M., and P. C. Trenham. 2001. Metapopulation dynamics and amphibian conservation. Conservation Biology $15: 40-49$. 
McLean, I. F. G., A. D. Wight, and G. Williams. 1999. The role of legislation in conserving Europe's threatened species. Conservation Biology 13:966-969.

Merola-Zwartjes, M., and J. P. DeLong. 2005. Avian species assemblages on New Mexico golf courses: surrogate riparian habitat for birds? Wildlife Society Bulletin 33:435-447.

Miaud, C. 1995. Oviposition site selection in three species of European newts (Salamandridae) genus Triturus. AmphibiaReptilia 16:265-272.

Nicholls, S., and J. L. Crompton. 2007. The impact of a golf course on residential property value. Journal of Sport Magazine 21:555-570.

Nilsson, C., and F. Götmark. 1992. Protected areas in Sweden: Is natural variety adequately represented? Conservation Biology 6:232-242.

Oldfield, T. E. E., R. J. Smith, S. R. Harrop, and N. LeaderWilliams. 2003. Field sports and conservation in the United Kingdom. Nature 423:531-533.

Oldham, R. S., D. M. Lathan, D. Hilton-Brown, M. Towns, A. S. Cooke, and A. Burn. 1997. The effect of ammonium nitrate fertilizer on frog (Rana temporaria) survival. Agriculture, Ecosystems and Environment 61:69-74.

Palmer, M. A., et al. 2005. Ecological science and sustainability for the 21st century. Frontiers in Ecology and the Environment 3:4-11.

Paton, P. W. C., and R. S. Egan. 2003. Strategies to maintain amphibian populations on golf courses. Exploring the roles of golf courses in the environment. USGA Green Section Record, July-August 2003.

Purse, B. V., G. W. Hopkins, K. J. Day, and D. J. Thompson. 2003. Dispersal characteristics and management of a rare damselfly. Journal of Applied Ecology 40:716-728.

Raloff, J. 1998. Common pesticide clobbers amphibians. Science News 154:150.

Rodewald, P. G., M. J. Santiago, and A. D. Rodewald. 2005. Habitat use of breeding red-headed woodpeckers on golf courses in Ohio. Wildlife Society Bulletin 33:448-453.

Rubbo, M. J., and J. M. Kiesecker. 2005. Amphibian breeding distribution in an urbanized landscape. Conservation Biology 19:504-511.

Ryals, S. C., M. B. Genter, and R. B. Leidy. 1998. Assessment of surface water quality on three eastern North Carolina golf courses. Environmental Toxicology and Chemistry 17:19341942.

Sahlén, G., and K. Ekestubbe. 2001. Identification of dragonflies (Odonata) as indicators of general species richness in boreal forest lakes. Biodiversity and Conservation 10:673690.

Samways, M. J., and N. S. Steytler. 1996. Dragonfly (Odonata) distribution patterns in urban and forest landscapes, and recommendations for riparian management. Biological Conservation 78:279-288.

SCB (Statistics Sweden). 2006. Statistical Yearbook of Sweden 2006. Volume 92. Edita Norstedts Tryckeri AB, Stockholm, Sweden.

Schindler, M., C. Fest, and A. Chovanec. 2003. Dragonfly associations (Insecta: Odonata) in relation to habitat variables: a multivariate approach. Hydrobiologia 497:169 180.

Scott, D. E., B. S. Metts, and J. W. Gibbons. 2002. Seasonal wetlands and golf courses. USGA Turfgrass and Environmental Research Online 1(4):1-7.

Scott, J. M., F. W. Davis, R. G. McGhie, R. G. Wright, C. Groves, and J. Estes. 2001. Nature reserves: do they capture the full range of America's biological diversity? Ecological Applications 11:999-1007.

Semlitsch, R. D., and J. R Bodie. 2003. Biological criteria for buffer zones around wetlands and riparian habitats for amphibians and reptiles. Conservation Biology 17:12191228.

Semlitsch, R. D., M. D. Boone, and J. R. Bodie. 2007. Golf courses could bolster amphibian communities. USGA Turfgrass and Environmental Research Online 6:1-16.

SGF (Svenska Golfförbundet). 1997. 〈http://sgf.golf.se/extra/ pod/?action $=$ pod_show\&id $=421 \&$ module_instance $=1\rangle$

SNV (Svenska Naturvårdsverket). 1999a. Bedömningsgrunder för miljökvalitet. Grundvatten. Naturvårdsverket Rapport 4915.

SNV (Svenska Naturvårdsverket). 1999b. Bekämpningsmedel förgiftar sjöar. Miljöaktuellt 4:3.

States of Jersey. 2007. Environmental protection and pesticide use. 〈http://www.gov.je/PlanningEnvironment/Environment/ Environmental+Protection/Environmental+Protec $\rangle$

Stewart, D. A. B., and M. J. Samways. 1998. Conserving dragonfly (Odonata) assemblages relative to river dynamics in an African savannah game reserve. Conservation Biology 12:683-692.

Tanner, R. A., and A. C. Gange. 2005. Effects of golf courses on local biodiversity. Landscape and Urban Planning 71: 137-146.

Watt, P. J., and R. S. Oldham. 1995. The effect of ammonium nitrate on the feeding and development of larvae of the smooth newt, Triturus vulgaris (L.), and on the behavior of its food source, Daphnia. Freshwater Biology 33:319-324.

Wellborn, G. A., D. K. Skelly, and E. E. Werner. 1996. Mechanisms creating community structure across a freshwater habitat gradient. Annual Review of Ecology and Systematics 27:337-363.

Welsh, H. H., and L. M. Ollivier. 1998. Stream amphibians as indicators of ecosystem stress: a case study from California's redwoods. Ecological Applications 8:1118-1132.

Wiederholm, T., and K. Johansson. 1999. Bedömningsgrunder för miljökvalitet. Sjöar och vattendrag. Naturvårdsverkets förlag, Stockholm, Sweden.

Wilbur, H. M., P. J. Morin, and R. N. Harris. 1983. Salamander predation and the structure of experimental communities - anuran responses. Ecology 64:1423-1429.

Winter, J. G., K. M. Somers, P. J. Dillon, C. Paterson, and R. A. Reid. 2002. Impacts of golf courses on macroinvertebrate community structure in Precambrian Shield streams. Journal of Environmental Quality 31:2015-2025.

Yasuda, M., and F. Koike. 2006. Do golf courses provide a refuge for flora and fauna in Japanese urban landscapes? Landscape and Urban Planning 75:58-68. 